http://dx.doi.org/10.18778/7969-549-2.12

\author{
Jacek Burski
}

Uniwersytet Łódzki

\title{
Relacja badacz-narzędzie - analiza konsekwencji użycia narzędzi komputerowych w analizie danych jakościowych na przykładzie QDA Miner
}

Streszczenie. W artykule skupiono się na relacji badacza i narzędzia, jakim jest program komputerowy QDA Miner służący do wsparcia analiz danych jakościowych (i nie tylko). Autor wychodzi z założenia o metawpływie narzędzia na działania badawcze. W tej perspektywie badacz, jeszcze w momencie planowania badania z wykorzystaniem programu komputerowego do analizy danych jakościowych, zaczyna "myśleć” programem. Oznacza to, że planowanie działań badawczych powinno uwzględnić szczegółową charakterystykę narzędzia, które posiada przecież unikalny zestaw możliwości wspomagających podstawową analizę. Możliwości wiążą się nierozerwalnie z ograniczeniami (kwestia rodzaju danych, które mogą być poddane analizie; możliwość pracy w grupie itp.). Charakter i zakres tych drugich może wyznaczać granice całego badania i mieć bezpośredni wpływ na wyniki procesu badawczego. Główne pytanie postawione w artykule dotyczy konsekwencji użycia techniki komputerowej do skomplikowanych analiz jakościowych, w których intuicja badacza oraz jego zdolności analityczne i syntetyczne powinny odgrywać główną rolę. QDA Miner jest w tym przypadku wykorzystany jako przykład aplikacji pozwalającej na archiwizację danych, strukturyzację bazy danych oraz działania analityczne prowadzące do końcowych wniosków.

Słowa kluczowe: techniki komputerowe w naukach społecznych, analiza jakościowa, QDA Miner.

\section{Wstęp}

Być może najlepszym początkiem artykułu o konsekwencjach wykorzystywania oprogramowania komputerowego w badaniach jakościowych będzie krótka historia własnych doświadczeń związanych z programem wspierającym badaczy społecznych, QDA Miner. W ramach projektu badawczego Cztery dyskursy nowoczesności - modernizm peryferii na przykładzie Łodzi (XIX-XX wiek), finansowanego przez Narodowe Centrum Nauki w ramach konkursu OPUS, zespół badawczy zdecydował się na wykorzystanie wsparcia komputerowego 
w przeprowadzaniu badania i analizach zebranego materiałuํํ․ Dla większości z nas było to pierwsze spotkanie z rozwiązaniem wychodzącym poza standardowy software biurowy. Początkowe nadzieje na kluczową rolę użycia oprogramowania w projekcie z czasem zmalały. Wstępne założenia projektu zakładające wprowadzenie analiz leksykometrycznych zostały zarzucone z powodów merytorycznych i logistycznych. QDA Miner stał się jednak podstawowym narzędziem do zarządzania liczącą kilkaset pozycji bazą artykułów prasowych, składających się na materiał empiryczny. Podczas przygotowywania artykułu trudno jednoznacznie ocenić, jaki wpływ na wyniki projektu będzie miał wybór oprogramowania, ale z dużą dozą pewności można postawić tezę na temat bardzo dużego wpływu wykorzystania programu komputerowego na elementy działania badawczego, szczególnie te związane z procesem organizacji, opisu i selekcji materiałów.

W artykule zamierzam zrekapitulować wnioski płynące z własnych doświadczeń w pracy z oprogramowaniem komputerowym, a także z tych opisywanych przez innych badaczy. Przede wszystkim chciałbym poddać bardziej szczegółowej analizie kwestie konsekwencji metodologicznych i epistemologicznych wykorzystania wsparcia technologii w procesie, nie tylko samej analizy, ale też innych elementów badania: projektowania, zbierania materiałów czy prezentacji jego wyników. Odnosząc się do idei gadamerowskiego koła hermeneutycznego (Gadamer 2004) jako metazasady działania badawczego - traktowania jako podstawy wysiłków badacza, by ciągle wracać, w stałej referencji między całością badania a jego częściami - można zaryzykować postawienie tezy o programie wspomagającym analizę jako mniej lub bardziej użytecznej platformie technologicznej, pozwalającej na usprawnienie ruchu od części do całości. Szczegółowe właściwości tej platformy określałyby możliwości badacza z niej korzystającego i jednocześnie, niejako na zasadzie odwrócenia, ograniczałyby jego pomysły i ambicje.

Pytanie jednak, czy waga wyboru oprogramowania nie jest na tyle duża, że powinniśmy zastanowić się nad wpływem jego implementacji na proces badawczy jeszcze zanim rozpoczniemy badanie właściwe. $W$ tekście próbuję zmierzyć się z problemem wpływu oprogramowania, zakładając, że często jest to czynnik nieuświadomiony i niepodejmowany przez badaczy, a taki może stanowić ukrytą barierę badania.

${ }^{1}$ Nie ma tu miejsca na szczegółowy opis zmagań badawczych w ramach tego projektu. Zainteresowanych zachęcam do zapoznania się z tekstem mojego współautorstwa (Burski, Brzeziński 2014).

2 Projekt cały czas trwa, a jego wyniki są dopiero w opracowaniu. Stąd, być może mylące, wymieszanie czasu przeszłego z przyszłym. 
W ramach niniejszego artykułu zastanawiam się nad:

- rozwojem nie tyle samego oprogramowania, co czynnikami wpływającymi na rosnącą popularność tego rodzaju rozwiązań. W tle próbuję wyjaśnić, w jaki sposób możemy analizować sukces programów komputerowych, których celem jest wspomożenie pracy badaczy preferujących podejście jakościowe, wykorzystując do tego celu koncepcje rozwoju nauki;

- wpływem oprogramowania na kolejne etapy procesu badawczego: przygotowanie koncepcji ( $w$ tym stworzenie struktury problemowej badania), zbieranie materiału (z wykorzystaniem różnych technik charakterystycznych dla metod jakościowych), analizę zebranego materiału i prezentację wyników badania;

- przedstawieniem, w jaki sposób program komputerowy „zadziałał w praktyce", czyli spróbuję zweryfikować opisane tezy w świetle własnych doświadczeń.

Decyzja o wykorzystaniu oprogramowania jest jednym z kluczowych elementów przygotowania badania. Waży na całym procesie badawczym, a w trakcie jego przeprowadzania może wymusić znaczące zmiany w projektowanym planie. Nie musi być to jednoznaczne wskazanie, że został popełniony błąd bądź wysiłki badacza zostały zmarnowane. Fundamentalną kwestią - nie tylko w przypadkach zmian w projekcie badawczym - jest jednak wysoki poziom samoświadomości w aspekcie ewentualnych zmian i wyborów. Dotyczy to także decyzji o wyborze konkretnego oprogramowania.

\section{Wykorzystanie oprogramowania komputerowego w perspektywie analizy relacji między badaczem a narzędziem}

Korzystanie z oprogramowania komputerowego przy analizie materiałów jakościowych nadal trudno uznać za powszechną praktykę wśród badaczy jakościowych. Szukając przyczyn takiego stanu, należy zwrócić się w stronę historii tego rodzaju narzędzi i, o czym dalej, ich wpływu na aspekty metodologiczne i epistemologiczne badania. Między innymi Niedbalski i Ślęzak (2012) wskazują na kilka kluczowych kwestii, które stały (i nadal stoją) na przeszkodzie w szerszym wykorzystaniu oprogramowania komputerowego w analizach jakościowych. Wśród najważniejszych problemów istotne znaczenie miała niechęć ze strony badaczy jakościowych do użytkowania narzędzi bezpośrednio łączonych ze skwantikowanym podejściem do analiz socjologicznych. U podstaw takiego sposobu myślenia leżało między innymi pragnienie podkreślenia odrębnej tradycji i odmiennego sposobu prowadzenia analiz niż w badaniach ilościowych, gdzie nowe technologie komputerowe przyjęły się znacznie szybciej (Niedbalski, Ślęzak 2012: 127). Wydaje się, że pomocne przy wyjaśnieniu wpływu tego czynnika będzie porównanie charakteru wiedzy 
zdobywanej z wykorzystaniem możliwości komputerów w przypadku prowadzenia badań ilościowych i jakościowych. Z reguły pierwszy rodzaj działania badawczego ma szeroki rozmach - kolekcjonowanie danych empirycznych obejmuje setki, a często tysiące osób; budowane z zebranego materiału bazy wymagają precyzyjnego i szybkiego narzędzia do analiz. Zalety komputerów są tu wyjątkowo uderzające - potencjał w przyspieszaniu i uwiarygodnianiu badania wyjaśnia ich szerszą recepcję w tej części świata badaczy społecznych, która preferuje badania o charakterze ilościowym. Patrząc szerzej, widać jak w ramach podejścia, które skłania się do paradygmatu nazywanego realistycznym, oprogramowanie komputerowe odpowiada na konkretną potrzebę wsparcia procesu badawczego, szczególnie tam, gdzie manualne procedowanie naraża badacza na błąd. Patrząc bardziej teoretycznie - w założonej relacji, gdzie badacz ma dostęp do badania i analizowania "jakiegoś" świata zewnętrznego, kluczowe jest zebranie i przeanalizowanie danych w taki sposób, by ich wiarygodność była bezsporna. Co ważne, takie założenie koresponduje z innym przeświadczeniem łączonym z paradygmatem realistycznym - o czystości metod obserwacji i analizy. W świetle słów Gibbsa (2011: 27), opisującego podejście realistyczne: „Świat istnieje tylko w jeden sposób. Nasze opisy i wyjaśnienia tego, co się w nim dzieje, są mniej lub bardziej dokładnymi sprawozdaniami, poprawnymi w takim stopniu, w jaki faktycznie odnoszą się do owego rzeczywistego świata", nie jest zaskoczeniem, że narzędzia dopracowujące i podnoszące poziom zaawansowania analiz owego świata zewnętrznego stały się immanentnym elementem wspomagającym praktykę badaczy ilościowych. Szczególnie, że technologia pozwala tu na rzekome spełnianie pozytywistycznych ideałów nauki - zbliża badacza do uzyskania pewnych i niepodważalnych sądów na temat rzeczywistości badanej. Jest orężem w walce o ich uprawomocnienie, co często jest dyskusyjne.

Niejako na zasadzie opozycji w przypadku podejścia jakościowego mamy do czynienia z perspektywą, która wprost zakłada, że przedmiotem badania nie jest zewnętrzna rzeczywistość. Ta, jeżeli w ogóle jest, znajduje się poza dostępem naszych zmysłów i aparatu myślowego. Jedynym dostępnym polem obserwacji i analiz jest więc sfera ludzkich wyobrażeń na jej temat:

Wszystko, co mówimy i czego doświadczamy, dokonuje się w drodze zapośredniczenia przez nasze konstrukty myślowe i aparat pojęciowy. Nawet sama idea rzeczywistości jest takim konstruktem. [...] Konstruktywizm stanowi pewną wersję idealizmu, która podkreśla, że na doświadczaną przez nas rzeczywistość składają się rozliczne i wielorakie, społecznie konstruowane rzeczywistości. Ich tworzenie wynika z faktu, że jednostki dążą do nadania sensu swoim doświadczeniom (Gibbs 2011: 29).

Słusznie zauważa się, że obydwie postawy (realistyczna i konstruktywistyczna) mają charakter typów idealnych i właściwie nie występują w stanie czystym (Benton i in. 2003). To, na co chciałbym zwrócić szczególną uwagę, jest raczej odnalezieniem wspólnego tonu, podobnej narracji, pomiędzy mówieniem o świecie 
w zorientowanym ontologicznie języku nauki a wykorzystywaniem do tego odpowiednich środków. Programy do analiz ilościowych wypełniają określoną lukę w warsztacie badacza i w ten sposób wzbogacają jego możliwości. Pozwalają mu mianowicie w sposób bezsporny stawiać i, co ważniejsze, weryfikować hipotezy na temat rzeczywistości. Stąd również moje przekonanie nie tyle o niechęci, ile stosunkowo trudnej do osiągnięcia kompatybilności technologii komputerowej z wizją konstruktywistyczną - dominującą w świecie analiz jakościowych. Badacze wybierający tego rodzaju podejście często nie potrafią znaleźć owej luki - powodu, dla którego wykorzystanie oprogramowania komputerowego może przynieść wymierne korzyści. Pozostając na gruncie wiary w tradycyjny warsztat i jego samowystarczalność, nie podejmują wyzwania pojawiającego się wraz z rosnącym zaawansowaniem i specyfikacją rozwiązań dostępnych dla badaczy jakościowych.

Nie bez znaczenia pozostaje również fakt różnic pokoleniowych. Dopiero ostatnie lata to okres wchodzenia do świata nauki badaczy socjalizowanych w wysoko zinformatyzowanym świecie. Dla nich technologia komputerowa i możliwości, jakie stwarza, to element tak naturalny w warsztacie badawczym, jak rola dyktafonu i dokładnej transkrypcji dla wcześniejszego pokolenia. Nie oznacza to oczywiście, że funkcjonuje jakaś konkretna cezura czasowa, która ostro rozgranicza zwolenników i przeciwników technologii komputerowej w analizach jakościowych. Szczególnie, że zalety implementacji programów często powodują, że postawa krytyczna zaczyna się zmieniać, a grono naukowców wykorzystujących oprogramowanie komputerowe coraz bardziej się powiększa.

Wśród powodów odwrócenia trendu należy przede wszystkim doszukiwać się wpływu na poziom usprawnienia działań. Bez wsparcia komputerowego część z nich wymagałaby więcej czasu i środków na realizację. Okazuje się, że odpowiednio zaprojektowany program komputerowy może znacząco ułatwić pracę nad materiałem. To, co kiedyś trzeba było wykonywać manualnie, przy wykorzystaniu aplikacji komputerowej może zostać przyspieszone i ułatwione. Podstawowe działania, takie jak kodowanie i wyszukiwanie, stają się stosunkowo proste, a wraz z rozwojem interfejsów kolejnych programów bariera między użytkownikiem a oprogramowaniem jest coraz mniejsza.

Warto również wrócić do kuhnowskiej teorii rewolucji naukowej. Wykorzystam ją tu do analizy dominacji określonych technik wspomagających działanie badawcze na podobnej zasadzie, jak w przypadku opisywanych przez Kuhna paradygmatów. Analogicznie można przecież rozpatrywać dominację podejść metodologiczno-technicznych. Krótko przypominając, Thomas Kuhn w swojej książce Struktura rewolucji naukowych (Kuhn 2009) przedstawił nowatorską analizę rozwoju nauki. Proces ten miał się opierać nie na klasycznie rozumianym kumulowaniu wiedzy, lecz na zdobywaniu uznania w świecie nauki przez paradygmaty, czyli kompleksy przekonań i założeń o badanej rzeczywistości. Niejako w ramach 
technologicznego oprzyrządowania metodologia i metody preferowane $\mathrm{w}$ danym paradygmacie również mogą się stać elementem rozpowszechniania i ostatecznie dominacji (aż do momentu, gdy nie pojawi się nowy paradygmat, który będzie lepiej odpowiadał na pojawiające się wątpliwości). Korzystając z tez Kuhna można przeprowadzić analizę pojawiania się i rozpowszechniania kolejnych koncepcji o jakościowym podejściu w naukach społecznych. Idąc tym tropem i poczynając od interakcjonizmu symbolicznego, przez etnometodologię, socjologię biografii, analizę dyskursu i jej odmiany czy teorię ugruntowaną (która ma jednak charakter bardziej metodologiczny niż część z wyżej wymienionych podejść), przechodzimy również kolejne etapy rozwoju metod i narzędzi wykorzystywanych do zbierania i analizowania materiału. Na początku dominowała technika obserwacji zaczerpnięta, bądź raczej współdzielona, z antropologią kulturową. Instytucja wywiadu zaczyna się rozpowszechniać wraz z pojawieniem się technologii pozwalającej na utrwalanie wypowiedzi badanego. Bez możliwości nagrywania i, co ważniejsze w przypadku analiz opartych na analizie konwersacyjnej, transkrypcji zebranego materiału niektóre dziedziny badania byłyby praktycznie niemożliwe. Przy bardzo szczegółowym zapisie istotne znaczenie ma możliwość edycji tekstu, a przy samej pracy kluczowa staje się kwestia łatwości użytkowania. Pojawienie się i popularyzacja komputerów osobistych znacząco rozwinęła możliwość wykonywania tego rodzaju działań badawczych. Kolejnym etapem wydaje się implementacja programów komputerowych służących do wspierania analizy jakościowej. Szczególnie istotne znaczenie miałby tego rodzaju proces dla eksploracji nowych pól badawczych, np. ogólnie ujętej problematyki socjologii wizualnej czy badania świata internetowego. Rozwój takich fenomenów społecznych, jak media społecznościowe (Facebook, Twitter, Instagram itp.) wymusza zmiany nie tylko na poziomie makroteoretycznym. Również warsztat badacza musi się dostosować do nowych wyzwań. Pojawienie się nowych technik nie oznacza jednak, że stare metody odchodzą w zapomnienie. Wręcz przeciwnie - ich rola nadal jest kluczowa, szczególnie gdy przywołamy ideę triangulacji jako kryterium dobrze przeprowadzonego badania jakościowego.

Wydaje się, że w przypadku tej części badaczy, którzy preferują analizę jakościową, dochodzi obecnie do momentu wyboru polegającego na otworzeniu się na wykorzystywanie oprogramowania komputerowego. Stawką tej decyzji jest szersze stosowanie oprogramowania do analizy różnego rodzaju materiału. Dla entuzjastów korzystania z technologii wydaje się jasne, że może to być bodziec znacząco rozwijający dziedzinę badań jakościowych (Ragin, Becker za: Miles, Huberman 2000).

Pojawiają się jednak wątpliwości, które stoją na przeszkodzie $w$ dalszym rozpowszechnianiu opisywanego paradygmatu. Przede wszystkim, zgodnie z badaniami Lee i Fieldinga (1998), głównym źródłem niepokoju jest kwestia relacji badacza i materiału. W przypadku komputerowego analizowania zebranego 
materiału wprowadzony zostaje dodatkowy pośrednik, którego nie ma, gdy badacz pozostaje na poziomie bardziej manualnego procesowania danych. To o tyle ciekawe, że jest to czynnik raczej o charakterze psychologicznym.

Ponadto wskazuje się na silne powiązanie wsparcia komputerowego z metodologią teorii ugruntowanej. Ten element krytyki zostaje podważony poprzez zwrócenie uwagi na to, że wraz z rozpowszechnianiem się oprogramowania do analiz jakościowych rośnie też liczba różnych wkomponowań teoretycznych i metodologicznych oprogramowania komputerowego. Tu posłużę się przykładem z własnych doświadczeń - opisywany przeze mnie w dalszej części artykułu projekt badawczy, w którym istotną rolę odgrywa wspomaganie komputerowe prowadzonych analiz jakościowych, jako podstawę metodologiczno-teoretyczną wykorzystuje postrukturalną teorię dyskursu, która wywodzi się z myśli Ernesto Laclau'a. To oczywiście nie jest jedyny możliwy przykład, ale dobrze ukazuje duży potencjał wsparcia komputerowego w różnego rodzaju badaniach.

Interesujące jest to, że właśnie badacze wykorzystujący teorię ugruntowaną jako jedni z pierwszych podjęli wysiłek włączenia programów wspierających analizę jakościową do własnej praktyki badawczej. Być może istotną rolę w tym procesie odegrała ogólna postawa metodologiczna charakteryzująca założenia teorii ugruntowanej, by w miarę możliwości ograniczać wpływ założeń i opierać się w działaniu badawczym na indukcji rozumianej jako proces, który polega na: wprowadzaniu i uzasadnianiu generalnego wniosku na podstawie dużej liczby pojedynczych, ale podobnych do siebie przypadków. Procedura wysycania kategorii, która sama w sobie jest przecież regułą nie tylko w badaniach prowadzonych przez badaczy zainspirowanych teorią ugruntowaną, opiera się na wnikliwej analizie zebranego materiału. Warunkiem jej poprawnego przeprowadzenia jest wydajne, spójne i systematyczne zarządzanie zebranymi danymi. W tym aspekcie kluczowe wydają się kolejne czynności, w których CAQDAS może znacząco ułatwić pracę: przeszukiwanie, kodowanie i wyszukiwanie. Wraz z rozwojem oprogramowania możemy się spotkać z funkcjami, które dodatkowo pozwalają na pogłębienie działań, których celem jest już nie tylko analiza zebranego materiału, lecz także synteza i tworzenie teorii w oparciu o zebraną empirię. Do tego mogą służyć narzędzia pozwalające na analizę własności i relacji w obrębie zebranych materiałów (Gibbs 2011).

\section{Wpływ oprogramowania komputerowego wspierającego analizę jakościową na proces badawczy}

W drugiej części artykułu chciałbym bardziej szczegółowo zająć się wpływem oprogramowania komputerowego na elementy procesu badawczego. Podstawowa struktura badania składa się z trzech głównych części: przygotowania 
koncepcji badania (w tym decyzji o wykorzystaniu wsparcia komputerowego), zebrania danych oraz analizy materiału. Dodatkowo, w zależności od ogólnych warunków, w których przychodzi działać badaczowi, (np. w sytuacji wnioskowania o grant badawczy) należy zwrócić uwagę na kwestie, które nie tyle są elementem struktury badania, ile wpływają na jego poszczególne etapy. Wśród tych czynników jednymi z najważniejszych są warunki logistyczne i finansowe, stanowiące - w kontekście analizowanego $\mathrm{w}$ artykule problemu - istotne tło wpływające na decyzję o wprowadzaniu do planu badawczego wsparcia komputerowego. Należy podkreślić, że część rozwiązań z rodziny CAQDA jest bezpłatna ${ }^{3}$ i dostęp do zróżnicowanego pola rozwiązań nie jest znacząco ograniczony. Jednakże, gdy interesują nas bardziej zaawansowane funkcje (np. rozszerzenia pozwalające na analizy leksykometryczne, jak w przypadku dodatku Wordstat dla programu QDA Miner), już przed rozpoczęciem badania powinniśmy wiedzieć, jakie rozwiązania nas interesują. Szczególnie, gdy musimy trzymać się określonego budżetu.

Marginalnym, lecz w niektórych momentach niezwykle istotnym elementem, jest też możliwość prezentacji części wyników, w czym również może nam wydatnie pomóc program komputerowy, na którym oparliśmy nasze działania analityczne. $W$ dobie dominacji logiki prowadzenia kariery naukowej w oparciu o zasadę „publish or perish” i coraz silniejszym przymusie, by prezentować swoje wyniki w ramach różnego rodzaju konferencji naukowych bądź warsztatów wagi nabiera możliwość przełożenia efektów pracy badawczej na estetycznie przystępny przekaz - taki, który poprawi jakość recepcji prezentowanych przez nas refleksji. Z punktu widzenia jakości analizy nie jest to oczywiście główna zaleta oprogramowania komputerowego, jednak jego wykorzystanie w tym celu może okazać się przydatne.

Zaczynając myśleć o badaniu społecznym, niekoniecznie jeszcze je kontekstualizując jako badanie jakościowe, ilościowe czy mieszane, rzadko zaczynamy od wyboru metodologii i, co za tym idzie, metod $i$ technik zbierania danych lub analizy. Nasza logika działania będzie raczej wychodzić od problemu, który nas interesuje. Chociaż, co spróbuję udowodnić, inne elementy badania (związane już z jego konkretną realizacją) mają wpływ już na te pierwsze konceptualizacje, to punkt startu refleksji badacza jest często podobny - jest nim zjawisko bądź problem, dopiero potem dokonuje się wyboru tego, co potrzeba do jego opisania bądź rozwikłania. Trudno jednak uznać, że badacz, zaczynając myśleć o konkretnym problemie, funkcjonuje w próżni teoretyczno-metodologicznej. Nie będzie przesadą stwierdzenie, że to, jakie problemy nas interesują i w jaki sposób w ogóle konceptualizujemy rzeczywistość społeczną oraz potencjalne sposoby jej

${ }^{3}$ Szerokie opracowanie dostępnych rozwiązań można znaleźć w książce Jakuba Niedbalskiego (Niedbalski 2013). 
wyjaśniania, zależy od naszych wewnętrznych przekonań, wartości i norm internalizowanych w toku edukacji i kariery naukowej. Ich ułożenie składa się na to, co niektórzy badacze nazywają paradygmatem (Lincoln, Guba 2000), światopoglądem (Creswell 2013) lub metodologią badań naukowych (Neuman 2010). Warunkowani jesteśmy również przez własne doświadczenia badawcze - praktyczną socjalizację w ramach określonych paradygmatów i zakres wiedzy posiadanej na temat metod i technik, którymi się posługujemy. Innymi słowy, już sam fakt zainteresowania się takim, a nie innym problemem nie jest pozbawiony kontekstu teoretyczno-metodologicznego. Zdanie sobie sprawy na samym początku z różnego rodzaju intuicji i powodów, które stoją za naszym wyborem problematyki ma istotne znaczenie w poprawnym zaprojektowaniu dalszego toku postępowania. Szczegółowy opis kroków, które należy podjąć bez względu na fakt zorientowania na bardziej jakościowe bądź ilościowe podejście, prezentuje Creswell w książce Projektowanie badań naukowych (2013). Do wymienionych wyżej elementów wpływających na ostateczny kształt projektu badawczego (problem badawczy i osobiste doświadczenia) autor dodaje kategorię odbiorców jako istotny czynnik:

[...] badacze piszą dla odbiorców, którzy powinni ich pracę zaakceptować. Odbiorcami są redaktorzy i czytelnicy czasopism naukowych, komisje naukowe, uczestnicy konferencji i inni badacze. Studenci powinni rozważyć zastosowanie ujęcia popieranego i stosowanego przez ich opiekunów naukowych (Creswell 2013: 45).

W sytuacji przygotowywania badania - określania problematyki, uszczegóławiania problemów badawczych, wskazywania celów i stawiania hipotez badawczych - wiedza o tym, czy i jaki program komputerowy będzie wykorzystywany do analizy danych, pozwala na bardziej szczegółowe i lepiej dopasowane wypracowanie określonych elementów. Wiedząc o tym, że na etapie analizy będziemy chcieli wykorzystać określone oprogramowanie możemy od razu dokonać wstępnej selekcji danych - zrezygnować z jakiegoś ich rodzaju bądź, co daje nam dużo większe możliwości, rozszerzyć zakres i rodzaj materiałów wchodzących do badania. Dobrym przykładem tego rodzaju praktyk mogą być badania, w których dokonujemy triangulacji materiału. Dzięki funkcjom pozwalającym na analizowanie zarówno materiałów tekstowych, jak i audiowizualnych możemy łączyć różne rodzaje danych, by wesprzeć i wzbogacić efekt badania.

W przypadku badań jakościowych mamy do czynienia z różnymi rodzajami technik kompletowania materiału badawczego. Wśród najważniejszych należy wymienić obserwację uczestniczącą, różne rodzaju wywiady (od wywiadów swobodnych podzielonych ze względu na poziom ustrukturyzowania do wywiadu narracyjnego), kolekcje danych zastanych czy wywiady fokusowe. Nie mam zamiaru przedstawiać tu obszernej charakterystyki każdego ze wskazanych sposobów zbierania danych. Czytelnik może takową znaleźć w kompendiach 
metodologicznych (Silverman 2008; Denzin, Lincoln 2014; Babbie 2008). Bardziej interesuje mnie kwestia relacji między wyborem techniki a późniejszym wykorzystaniem programu komputerowego wspierającego analizę materiału zebranego tą techniką.

Kluczowe wydaje się poświęcenie odpowiedniej ilości czasu na wskazanie nie tylko, o jaki rodzaj danych nam chodzi, ale także, jakie cele chcemy w ramach analizy tych danych osiągnąć. Innymi słowy, relacja między oprogramowaniem komputerowym a techniką zbierania danych w wielu przypadkach zależy od postawionych hipotez. Inny program będzie nas interesował przy zbieraniu i opracowywaniu danych pod kątem analiz dyskursywnych (tu chociażby istotnym warunkiem może się okazać kwestia wbudowania słownika w program bądź możliwości jego stworzenia), a inne podejście do wyboru programu będziemy mieć, jeżeli jesteśmy zainteresowani łączeniem analiz tekstu i materiałów audiowizualnych.

Kluczowym elementem badania, niejako zwieńczającym wysiłek badacza, jest przejście do analizy zebranego materiału, w ramach której postawione przed i w trakcie badania hipotezy są weryfikowane. Można zaryzykować tezę, że w przypadku badań jakościowych pierwsze wnioski o charakterze analitycznym pojawiają się wraz $z$ etapem zbierania danych. Kontakt między badaczem a materiałem badanym - bez względu na źródło jego pochodzenia, czy jest to relacja z wywiadu, czy artykuł prasowy - wiąże się z powstaniem wrażeń i intuicji na temat kolekcjonowanych danych. W sensie metodologicznym można wykorzystać tę sytuację i za pomocą chociażby notatek tworzonych w trakcie zbierania danych wspierać późniejsze działania analityczne. Programy komputerowe właściwie zawsze posiadają możliwość tworzenia różnego rodzaju notatek. Jest to o tyle wygodne, że w przypadku scentralizowanego zarządzania danymi możemy bezproblemowo korzystać z tego rodzaju dodatkowych danych.

Sama analiza danych w przypadku wykorzystywania oprogramowania komputerowego - przede wszystkim - pozwala skupić się na działaniach związanych z przeszukiwaniem powstałej bazy danych oraz kodowaniem. Szczególnie możliwość zarządzania strukturą kodów, ich swobodnego tworzenia i zmieniania, jest niezwykle istotna przy obróbce większych zbiorów. Co ważne, na co zwraca uwagę Flick (2012), oprogramowanie komputerowe wspierające QDA pozwala na podwyższanie poziomu prowadzonego badania poprzez otwieranie możliwości na mieszanie nie tylko różnego rodzaju danych jakościowych, lecz także na łączenie ich z danymi o charakterze ilościowym. W przypadku programu QDA Miner mamy możliwość nie tylko obsługi różnych danych, ale prowadzenia na tym samym korpusie działań analitycznych również za pomocą dodatku statystycznego Wordstat. Dodanie tego rodzaju analiz znacząco poszerza horyzont badawczy i może przyczynić się do pogłębienia wyników badania. 


\section{Wpływ oprogramowania na praktykę badawczą - analiza przypadku}

W ramach podsumowania powyższych rozważań chciałbym krótko podzielić się doświadczeniami z projektu badawczego, w którym konkretne oprogramowanie (QDA Miner) zostało wykorzystane jako platforma do przeprowadzenia analiz o charakterze jakościowym. Ze względu na charakter tekstu nie jest moim celem opisywanie szczegółowych założeń projektu. Skupię się jedynie na informacjach odnoszących się do aspektu metodologicznego, które pozwolą się czytelnikowi zorientować, do jakich celów program został wykorzystany.

Przede wszystkim należy wskazać, że na materiał stanowiący podstawę analiz składały się materiały prasowe pochodzące z różnych epok historycznych. Skolekcjonowanie i skatalogowanie korpusu danych wymagało wykorzystania różnego rodzaju narzędzi (skanerów, aparatu fotograficznego, w części możliwe było realizowanie kwerend za pośrednictwem Internetu w związku z cyfryzacją niektórych zbiorów). To z kolei zrodziło problem związany ze stworzeniem bazy jednolitej pod względem formatów. Został on rozwiązany poprzez konwersję danych na jeden format. Zanim jednak do tego doszło z setek artykułów zostały wybrane jedynie te, które uznano za najbardziej wartościowe pod kątem prowadzonych analiz. Pliki graficzne zostały przekonwertowane na pliki tekstowe i jako takie trafiły do kolejnego etapu analizy. W związku z tym, że w momencie pisania niniejszego artykułu etap ten nadal nie jest zakończony, nie mogę przedstawić tu żadnych końcowych wyników. Możliwe jest jednak wskazanie na wpływ właściwości tego konkretnego oprogramowania na podejmowane działania badawcze.

Po pierwsze, wybór programu był uzależniony od kilku czynników m.in.: możliwości połączenia analiz jakościowych z ilościowymi, swobody korzystania przez wieloosobowy zespół z bazy danych oraz planowanego budżetu. Z perspektywy tego artykułu najbardziej istotne wydaje się pierwsze kryterium, które w praktyce okazało się najtrudniejsze do spełnienia. Tak jak wspomniałem, materiały prasowe, na których jest prowadzona analiza, pochodzą z różnych momentów historycznych oddalonych od siebie o kilkanaście, a czasami kilkadziesiąt lat. To powoduje, że język, który pojawia się w korpusie danych, znacząco różni się w ramach kolejnych kwerend. Okazało się to o tyle istotne, że zmusiło zespół badawczy do ograniczenia zakresu analiz o charakterze leksykometrycznym, które miały wesprzeć główne działania analityczne. Dzięki wyposażeniu programu w rozbudowane możliwości badania relacji między poszczególnymi kodami w tej jego części, która poświęcona jest analizie stricte jakościowej (np. możliwość ustalania referencji między poszczególnymi kodami), główne cele badawcze ukierunkowane na weryfikację ogólnie pojętych strategii dyskursywnych odnoszących się do idei nowoczesnego miasta cały czas są możliwe do osiągnięcia. Pozostałe czynniki - swoboda w korzystaniu z programu przez wieloosobowy zespół 
oraz kwestie finansowe - nie sprawiły dotychczas problemów. Tu warto dodać, że w przypadku planowania użytkowania jednego z płatnych programów warto zastanowić się nad logistycznymi możliwościami nie tylko dostępu do oprogramowania (sprawę ostatecznie może rozwiązać większa liczba licencji), lecz także nad mocą przerobową posiadanych komputerów. Rzecz wydaje się banalna, ale przy obsłudze dużych baz danych (np. w przypadku analiz wizualnych zdjęć) działający wolno komputer znacząco spowalnia pracę badacza.

Z perspektywy czasu, analizując powody, dla których zdecydowaliśmy się na wprowadzenie do projektu badawczego wsparcia komputerowego, należy podkreślić, że pomimo przeprowadzonego wywiadu na temat dostępnych rozwiązań, właściwą wiedzę na temat przydatności wybranego przez nas programu uzyskaliśmy dopiero podczas prowadzenia badania. Część założonych celów musiała ulec zmianie. Wpływ na to miał szereg przyczyn - od braku doświadczenia w prowadzeniu tego rodzaju analiz, przez niewystarczające wysondowanie rynku, po zwyczajnie zbyt szeroko zaprojektowane badanie. Pomimo ograniczenia niektórych założeń badawczych z dużą pewnością mogę stwierdzić, że wykorzystane oprogramowanie komputerowe podniosło jakość pracy nad materiałem.

\section{Zakończenie}

W artykule starałem się przedstawić swoje wątpliwości dotyczące wykorzystywania oprogramowania komputerowego w analizie danych jakościowych, opierając się na własnych doświadczeniach z określonym rozwiązaniem - programem QDA Miner. Będąc użytkownikiem tej aplikacji i czynnym uczestnikiem dyskusji na temat jej przydatności przy realizacji określonego projektu badawczego, zastanawiałem się nad wpływem samego oprogramowania na działania badacza. Często mamy przecież poczucie kontroli i sprawczości nad procesem badawczym - to my jesteśmy konstruktorami jego głównych założeń: sposobu widzenia problemu, metod jego analizy, decyzji o konkretnych technikach zbierania danych, wyboru grupy badanej. Byłoby jednak naiwne sądzić, że badacz odpowiada za całość wykreowanego społecznego świata badania. Są przecież elementy nieuświadomione i to nie tylko te, które mają swoje zakorzenienie $w$ światopoglądzie badacza. Jednym z tego rodzaju czynników jest właśnie oprogramowanie komputerowe. Jego charakter jest przecież całościowo zewnętrzny - zostało stworzone nie jako odpowiedź na potrzebę konkretnego działania badawczego, ale jako uniwersalna (do pewnego poziomu) platforma służąca do wykonywania czynności immanentnie związanych z prowadzeniem badań. Idąc dalej tym tropem, nasuwa się pytanie: jakie są konsekwencje dla procesu badawczego w przypadku zastosowania programu komputerowego - epistemologiczne i metodologiczne? 
Wydaje się, że w kontekście pytania o ewentualną zmianę jakości poznania, oprogramowanie komputerowe ma charakter ambiwalentny $-z$ jednej strony zwiększa potencjał analityczny poprzez usprawnienie działania, skrócenie procedur, zapewnienie jednolitości i efektywności w wyszukiwaniu: „[...] w przypadku analizy jakościowej kodowanie jest sposobem na uporządkowanie danych, na zarządzanie surowym materiałem badawczym. Oznacza to, że wszystkie oryginalne dane zostają zachowane" (Gibbs 2011: 24).

$Z$ drugiej strony, powoduje, że badacz $w$ dużej mierze zdaje się $w$ procesach kodowania i wyszukiwania na reguły rządzące danym programem. Reguły, jakkolwiek prowadzące do wzrostu efektywności, pozostają poza jego kontrolą. Być może tu należy doszukiwać się przyczyn stosunkowo powolnego rozpowszechniania się technologicznego wsparcia w analizach jakościowych.

W sensie metodologicznym oprogramowanie komputerowe nie może być traktowane jako zwykłe narzędzie, które - metaforycznie rzecz ujmując - pozwala szybciej i mocniej dokręcić śrubę naszych działań analitycznych. Chociażby z powodu jego zewnętrznej natury, namysł nad skorzystaniem i umiejscowieniem programu w planowanym projekcie badawczym musi mieć istotne znaczenie. Podając własny przykład, wskazałem, w jaki sposób program może zaskoczyć niedoświadczonego badacza. W takich sytuacjach im jesteśmy bardziej świadomi własnego badania i jego metodologii, tym łatwiej będzie nam się dostosować do możliwości programu i zachować cele istotne dla samego badania.

Dodatkowym atutem programów z rodziny CAQDA jest otwarcie procedur analitycznych na działania mające na celu łączenie perspektywy ilościowej i jakościowej. Badania ilościowe i jakościowe nie powinny być traktowane jako przeciwieństwa, ale raczej jako „punkty krańcowe pewnego kontinuum” (Creswell 2013; Newman, Benz 1998: 29), a oprogramowanie komputerowe może stać się doskonałą platformą do łączenia obydwu perspektyw. Chociażby z tego ostatniego powodu warto w trakcie projektowania własnych kroków badawczych zastanowić się nad wprowadzeniem wspomagania komputerowego do analiz jakościowych.

\section{Bibliografia}

Babbie Earl Robert (2008), Podstawy badań społecznych, Wydawnictwo Naukowe PWN, Warszawa.

Benton Ted, Craib lan (2003), Filozofia nauk społecznych: od pozytywizmu do postmodernizmu, Wydawnictwo Dolnośląskiej Szkoły Wyższej Edukacji TWP, Wrocław.

Burski Jacek, Brzeziński Kamil (2014), Próba wykorzystania programu komputerowego QDA Miner do realizacji projektu badawczego "Cztery dyskursy o nowoczesności - modernizm peryferii na przykładzie Łodzi (XIX-XX wiek)”, „Przegląd Socjologii Jakościowej”, vol. 10, no. 2, s. 26-43; www.przegladsocjologiijakosciowej.org [dostęp: 1.06.2014]. 
Creswell John (2013), Projektowanie badań naukowych: metody jakościowe, ilościowe i mieszane, Wydawnictwo Uniwersytetu Jagiellońskiego, Kraków.

Denzin Norman, Lincoln Yvonna (2014), Metody badań jakościowych, Wydawnictwo Naukowe PWN, Warszawa.

Fielding Nigel, Lee Raymond (1998), Computer Analysis and Qualitative Research, Sage, London. Flick Uwe (2012), Projektowanie badania jakościowego, Wydawnictwo Naukowe PWN, Warszawa. Gadamer Hans-Georg (2004), Prawda i metoda: zarys hermeneutyki filozoficznej, Wydawnictwo Naukowe PWN, Warszawa.

Gibbs Graham (2011), Analizowanie danych jakościowych, Wydawnictwo Naukowe PWN, Warszawa.

Kuhn Thomas (2009), Struktura rewolucji naukowych, Wydawnictwo Aletheia, Warszawa.

Lincoln Yvonne, Guba Egon (2000), Naturalistic Inquiry, Calif: Sage Publications, Beverly Hills.

Miles Matthew, Huberman Michael (2000), Analiza danych jakościowych, Trans Humana, Białystok.

Neuman Lawrence (2010), Social Research Methods: Qualitative and Quantitative Approaches, edition with: MyResearchKit, Prentice Hall, New Jersey.

Newman Isadore, Benz Carolyn (1998), Qualitative-Quantitative Research Methodology: Exploring the Interactive, IL: Southern Illinois University Press, Continuum Carbondale.

Niedbalski Jakub (2013), Odkrywanie CAQDAS: wybrane bezpłatne programy komputerowe wspomagajqqce analizę danych, Wydawnictwo Uniwersytetu Łódzkiego, Łódź.

Niedbalski Jakub, Ślęzak Izabela (2012), Analiza danych jakościowych przy użyciu programu NVivo a zastosowanie procedur metodologii teorii ugruntowanej, „Przegląd Socjologii Jakościowej", vol. 8, no. 1, s. 126-65; www.przegladsocjologiijakosciowej.org [dostęp: 1.03.2014].

Silverman David (2008), Prowadzenie badań jakościowych, Wydawnictwo Naukowe PWN, Warszawa.

\section{Researcher - Computer Programme Relation. Consequences of Using Computer Programme in Qualitative Data Analysis. QDA Miner in Practice}

Summary. Proposed article is focused on description of relation between researcher and programme which is used to support qualitative analysis in social research. In this particular case, QDA Miner was used to show how computer support impact on not only analytical processes but whole research project in general as well. Theoretical background for these reflections is connected with understanding ambivalent nature of using computer programme in qualitative data analysis - not only as positive support but as barrier as well. Main question is what are consequences of using technological support in analysis? I am going to answer to that with paying attention to two main aspects of the research: epistemological and methodological.

Keywords: computer programmes in social research, qualitative data analysis (QDA), QDA Miner. 